\title{
Germinated Wheat Starch as a Substrate to Produce Cyclodextrins: Application in Inclusion Complex to Improve the Thermal Stability of Orange Essential Oil
}

\author{
Dianini Hüttner Kringel, Julia Baranzelli, Jéssie Da Natividade Schöffer, \\ Shanise Lisie Mello El Halal,* Martha Zavariz De Miranda, Alvaro Renato Guerra Dias, \\ and Elessandra Da Rosa Zavareze
}

Wheat pre-harvest sprouting (PHS) is caused by high rainfall especially when the grain is in the filling stage. PHS decreases the grain yield, and is harmful to flour technological quality for baking, with a consequent decrease in economic value. However, the amylolytic activity promoted by germination can facilitate the production of cyclodextrin (CDs). The influence of germinated wheat starch concentration (1\% and 10\%) on the production of $\alpha$, $\beta$, and $\gamma-C D$ is verified. In addition, the thermal stability of the inclusion complex between CDs produced from germinated wheat starch and orange essential oil (CDs/OEO) is also evaluated. The germination promotes the highest conversion yield (54.4\%) at the lowest starch concentration (1\%) used. The CDs/OEO increase the orange essential oil thermal stability, promoting their protection at high temperatures. Therefore, this study shows that germinated wheat starch is a promising substrate for the cyclodextrin production, adding value to this product that is, normally, not used by the food industry, but for animal nutrition or discarded. occurs especially near the time of harvest, resulting in a decreased yield and an impaired quality of the grain, as well damages in the extraction and technological quality of the flour, decreasing their economic value. ${ }^{[1]}$

Our research group studied the effect of germination in several aspects. Baranzelli et al. ${ }^{[2]}$ reported the increase in specific volume, firmness, and gamma-aminobutyric acid (GABA) content in bread made from germinated wheat flour. Baranzelli et al. ${ }^{[3]}$ studied the impact of wheat germination on starch properties for application in films and showed that germination promotes an increase in enzymatic activity, swelling power, and solubility of starches and a decrease in their relative crystallinity. Besides that, germination process increased in the tensile strength and elongation of the starch films.

The increase of amylolytic activity reported by Baranzelli et al. ${ }^{[3]}$ promotes an increase in reducing sugars, such as maltose and glucose, and also dextrins and oligosaccharides that would facilitate the production of cyclodextrins (CDs), since these are produced by hydrolysis followed transglycosylation reactions, besides avoiding the additional use of amylase prior to CD glycosyltransferase (CGTase).

CDs are produced from enzymatic hydrolysis, catalyzed by the CD glycosyltransferase enzyme and the starch is the main substrate. ${ }^{[4]}$ CDs have capacity to form inclusion complexes with hydrophobic guest substances promoting an increase in light and temperature stability, provides protection against oxidation, masks or reduces undesired physiological effects, and reduces its volatility. ${ }^{[5]}$

The starch source influences the characteristics of CDs. Several authors studied different starch sources as a substrate for the production of $\mathrm{CDs}^{[6,7]}$ as well the CDs production with agroindustry by-products in order to reduce costs. ${ }^{[8]}$ However, no reports have been found using the germinated wheat starch for this purpose. This study aims to produce of CDs $(\alpha, \beta$, and $\gamma$-CD) using germinated wheat starch as substrate and evaluated the thermal stability of inclusion complex between these CDs and orange essential oil (OEO).
The ORCID identification number(s) for the author(s) of this article can be found under https://doi.org/10.1002/star.201900083

DOI: 10.1002/star.201900083 
Table 1. Extraction yield and chemical composition of the germinated and non-germinated wheat starch.

\begin{tabular}{lcc}
\hline Parameters [\% d.b.] $]^{\text {a) }}$ & Germinated & Non-germinated \\
\hline Extraction yield & $45.83 \pm 1.35^{*}$ & $64.83 \pm 1.27$ \\
Moisture & $8.96 \pm 0.25^{\mathrm{ns}}$ & $8.73 \pm 0.21$ \\
Ash & $0.208 \pm 0.001^{*}$ & $0.140 \pm 0.005$ \\
Lipids & $0.107 \pm 0.002^{*}$ & $0.097 \pm 0.002$ \\
Crude protein $(\times 5.7)^{\mathrm{b})}$ & $0.312 \pm 0.015^{\mathrm{ns}}$ & $0.332 \pm 0.011$ \\
\hline
\end{tabular}

a) Results expressed on dry basis; b) Nitrogen conversion factor. The results are the means of three determinations. Values with $*$ and ns significant and not signifi cant, respectively, by $t$-test $(p \leq 0.05)$ between non-germinated and germinated wheat starches.

\section{Results and Discussion}

\subsection{Extraction Yield and Chemical Composition of the Starch}

The extraction yields and chemical compositions of the germinated and non-germinated wheat starches are shown in Table 1. The starch extraction yield was reduced after germination. A similar result was also reported by Pinkaew et al. ${ }^{[9]}$ for three rice cultivars and attributed to the decomposition of native starch by hydrolytic enzymes, resulting from germination. These enzymes, including $\alpha$-amylase, $\beta$-amylase, and $\alpha$-glucosidase, can degrade starch granules and thereby produce maltose, glucose, dextrins, and oligosaccharides. ${ }^{[10]}$

According to Pinkaew et al. ${ }^{[9]}$ the isolation of starch involves the removal of protein. Thus, a higher starch extraction yield is followed by lower protein content. Even though a significant difference was observed in the yield of starch, the germination did not induce changes in crude protein content or in the moisture content of the starch. Xu et al. ${ }^{[10]}$ revealed that protein content after germination is related to the molecular weight of proteins; whereas high molecular weight proteins are to a certain extent hydrolyzed during the initial stage of germination, proteins with low molecular weight remain nearly the same.

Germination promoted a significant increase of ash content. This increase can be due hydrolysis of the nutrient inhibitors, such as phytic acid, promoted by germination, leading to release phosphate and minerals. ${ }^{[11]}$ According to Kajla et al. ${ }^{[12]}$ during germination about $70 \%$ of phosphorous is converted into soluble free phosphorous by the action of phytase, which consequently increase of the ash content.

The germination also provides an increase of the lipid content. The loss of starch due to germination leads to consequent decrease of weight; thus, the percentages of the other components can change as a proportion of total weight. ${ }^{[13]}$

\subsection{Amylolytic and Alpha-Amylase Activities in the Wheat Milled Grains and Starch}

The amylolytic and alpha-amylase activities in milled grains from germinated and non-germinated wheat were higher than the values found for their respective starches (Figure 1). The highest enzymatic activity in whole wheat compared with starch is explained by the action of enzymes located beneath the aleurone layer and, to a lesser extent, in the germ. ${ }^{[14]}$ Moreover, during the starch extraction process, the enzymes may have been removed, which along with the solubility of the proteins, might have contributed to the lower enzymatic activity of starch compared with the ground grain of wheat.

Germinated wheat starch showed higher values of amylolytic (0.89 $\left.\mathrm{U} \mathrm{mL}^{-1}\right)$ and alpha-amylase $\left(0.82 \mathrm{U} \mathrm{mL}^{-1}\right)$ activities compared to the non-germinated starch, of which values were 0.27 and $0.72 \mathrm{U} \mathrm{mL}^{-1}$ for amylolytic and alpha-amylase activities, respectively. Endogenous amylases, which are synthesized in the aleurone layer, are activated during germination and are responsible for the degradation of the starchy endosperm. ${ }^{[15]}$ Alpha-amylase constitutes $\approx 30 \%$ of the total enzymes synthesized during germination and plays a major role in starch hydrolysis, acting primarily as a liquefying enzyme during the germination process. ${ }^{[16]}$

De Brier et al. ${ }^{[17]}$ reported that alpha-amylase can persist in mature and non-germinated wheat grains at levels sufficient to affect the enzymatic activity of flours, which explains the alphaamylase activity in non-germinated wheat $\left(3.82 \mathrm{U} \mathrm{mL}^{-1}\right)$, while the germinated wheat exhibited a higher alpha-amylase activity (5.97 $\left.\mathrm{U} \mathrm{mL}^{-1}\right)$.

\subsection{Production of CDs from Wheat Starch}

The production of CDs was influenced by starch concentration (Table 2). When the highest starch concentration was used (10\%), in both germinated and non-germinated wheat starches, the number of $\gamma$-CDs increased, while the concentrations of $\alpha$ - and $\beta$-CDs decreased continuously during the reaction. On the other hand, at a lower starch concentration $(1 \%)$ the $\beta$-CDs production predominated. The proportion of CDs was dependent on the initial substrate concentration and on reaction time. ${ }^{[7]}$ Ibrahim et al. ${ }^{[8]}$ produced CDs using different concentrations of potato starch $(0.5-5.0 \%)$ as substrate. These authors found a higher conversion rate using a concentration of $1.5 \%$ starch than with a concentration of $5.0 \%$ starch. They also reported that the production of CDs can be prevented either by inhibiting the action of CDs produced using CD glycosyltransferase, or by a high dextrose equivalent; and this may explain the low yield of CDs, along with the low rate of conversion at higher starch concentrations.

Sakinah et al. ${ }^{[18]}$ evaluated the effect of different concentrations of tapioca starch and CD glycosyltransferase on CD production, and reported higher concentrations of CDs at lower starch concentrations. However, the increase in the concentration of tapioca starch (above $8 \% \mathrm{w} / \mathrm{v}$ ) did not result in a significant increase in total CD production. This is due the starch active sites becoming saturated at higher starch concentrations, whereas the concentration of CD glycosyltransferase remained constant, resulting in a negligible CD yield.

Schöffer et al. ${ }^{[19]}$ studied the effect of substrate concentration on $\beta$-CD production, with soluble starch concentrations varying from $0.2 \%$ to $10 \%$, and reported that the maximum conversion yield occurred at a low starch concentration (4\%). According to Rakmai and Cheirsilp, ${ }^{[20]}$ the reduction in the concentration of $\beta$-CD using a high concentration of substrate is due 


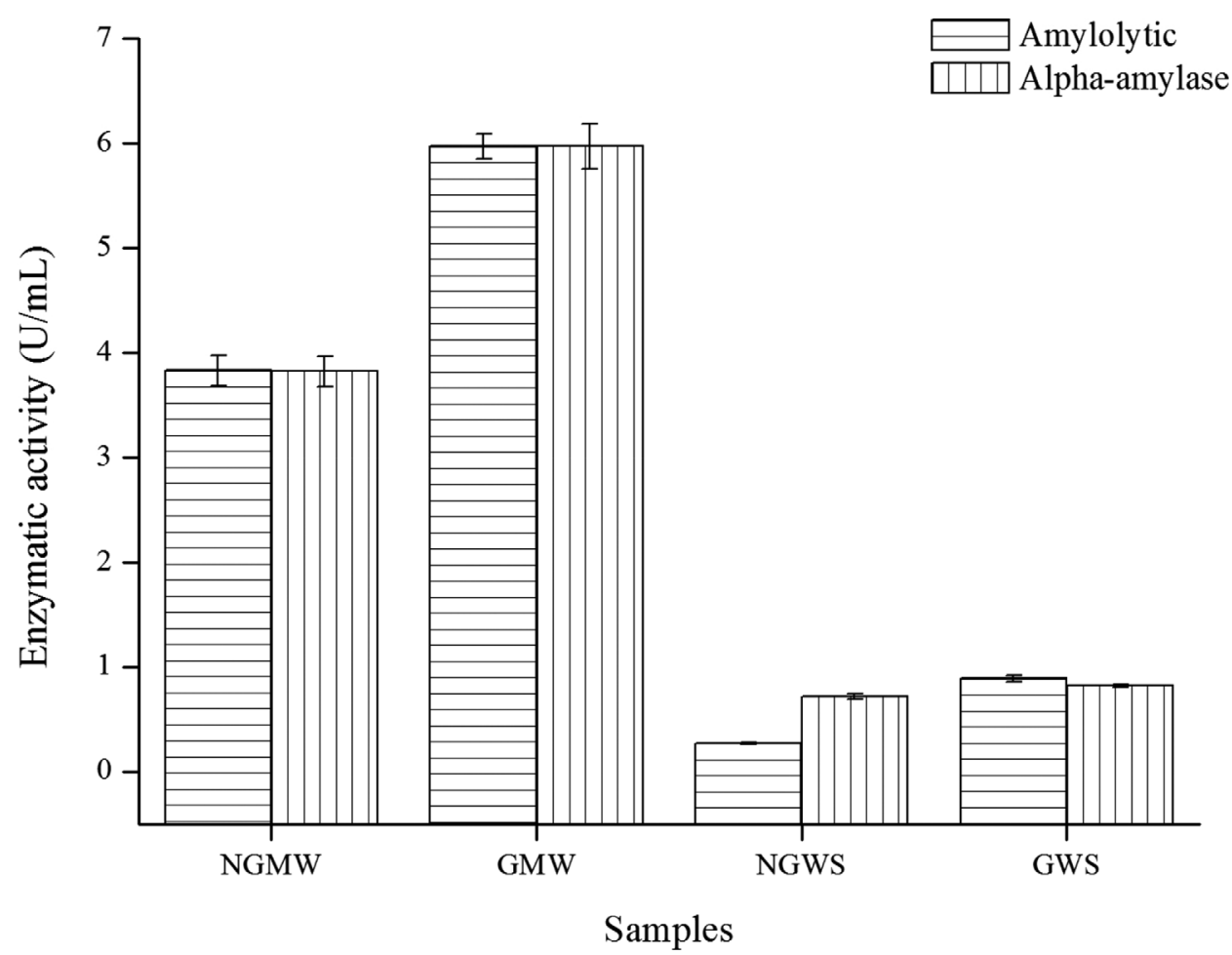

Figure 1. Enzymatic activity (amylolytic and alpha-amylase) of wheat grains and wheat starches. NGMW, non germinated milled wheat; GMW, germinated milled wheat; NGWS, non germinated wheat starch; GWS, germinated wheat starch.

Table 2. Concentrations of $\alpha-, \beta$-, and $\gamma$-cyclodextrins and conversion yield of germinated and non-germinated wheat starches.

\begin{tabular}{|c|c|c|c|c|c|c|c|c|}
\hline \multirow[t]{2}{*}{ Wheat starch } & \multirow[t]{2}{*}{ Starch [\%] ${ }^{\mathrm{a})}$} & \multicolumn{3}{|c|}{ Cyclodextrins [mg mL $\left.{ }^{-1}\right]$} & \multicolumn{3}{|c|}{ Cyclodextrins [\%] } & \multirow[t]{2}{*}{ Conversion yield $[\%]^{b}$} \\
\hline & & $\alpha$ & $\beta$ & $\gamma$ & $\alpha$ & $\beta$ & $\gamma$ & \\
\hline \multirow[t]{2}{*}{ Germinated } & 1 & 0.04 & 5.00 & 0.40 & 1.30 & 90.25 & 8.45 & 54.4 \\
\hline & 10 & 3.29 & 3.09 & 6.52 & 36.40 & 18.52 & 45.12 & 12.9 \\
\hline \multirow[t]{2}{*}{ Non germinated } & 1 & 0.04 & 4.42 & 0.40 & 1.42 & 89.06 & 9.52 & 48.6 \\
\hline & 10 & 3.02 & 2.75 & 6.55 & 35.00 & 17.60 & 47.45 & 12.3 \\
\hline
\end{tabular}

a) Concentration of starch in relation to the buffer solution $(\mathrm{w} / \mathrm{v}) ;{ }^{\text {b) }} \mathrm{mg}$ cyclodextrin/100 $\mathrm{mg}$ starch.

to the inhibition of the CGTase by the end products. Moreover, high concentrations of starch also cause an increase in viscosity, which hinders the access of enzymes to their substrate.

The germination process of wheat influenced the CD production promoting the highest conversion yield (54.4\%) at the lowest starch concentration (1\%) used. During germination, several changes in the grain were observed, including increased amylolytic enzymes activated by mechanisms that regulate the process of germination. ${ }^{[21]}$ The presence of these enzymes might have contributed to the observed difference in the production of CDs.

Since the germination process decreases the technological quality of wheat flour for making bread, an alternative could be to isolate the germinated wheat starch for use in the production of CDs, as this would represent a way to add value to a product that would otherwise be discarded by the food industry.

\subsection{Reducing Sugars in the CDs Produced from Wheat Starch}

The reducing sugars content in the CDs produced from wheat starch is shown in Table 3. Although CGTase belongs to the $\alpha$-amylase family, this enzyme mainly catalyzes intramolecular cyclization. ${ }^{[22]}$ Therefore, the starch was traditionally subjected to a pretreatment using amylase prior to CGTase. However, the additional use of amylase has several disadvantages, such as the degradation of CDs and a low yield due to acceleration of other CGTase reactions through coupling. ${ }^{[23]}$ In this context, the use of wheat starch previously liquefied by amylases produced during germination could be an alternative to overcome these problems.

The germination process increased the reducing-sugars content, possibly due to the presence of $\alpha$ and $\beta$-amylase enzymes. According to Wang et al., ${ }^{[22]}$ treatment with liquefying enzymes can produce high quantities of glucose, which could facilitate the 
Table 3. Reducing sugars content of the cyclodextrins produced with starch from germinated and non-germinated wheat starches.

\begin{tabular}{lcc}
\hline Wheat starch & Concentration of starch [\%] & Reducing sugars $\left.\left[\mathrm{mg} \mathrm{mL}^{-1}\right]^{\mathrm{a}}\right)$ \\
\hline Germinated & 1 & $0.43 \pm 0.07^{\mathrm{c}}$ \\
& 10 & $0.97 \pm 0.00^{\mathrm{a})}$ \\
Non-germinated & 1 & $0.39 \pm 0.01^{\mathrm{d}}$ \\
& 10 & $0.89 \pm 0.00^{\mathrm{b}}$
\end{tabular}

a) $\mathrm{mg}$ of glucose for $\mathrm{mL}$ of cyclodextrins solution. Each value is the mean of three experiments. Mean \pm SD. Values with different letters in the same column are significantly different $(p<0.05)$

coupling reaction with CDs. Confirming this statement, the germinated wheat starch presented the highest content of reducing sugars, and consequently, the highest CDs yield (Table 2).

The results found in this research are in agreement with previous findings by $\mathrm{Xu}$ et al. ${ }^{[10]}$ who showed an inverse relationship between starch extraction yield and reducing sugar content, when the germination caused a reduction in total starch content, but an increase in the level of reducing sugars. This is due to cleavage of the $\alpha-1,4$ glycosidic linkages of starch produced by amylases during germination and thereby release products such as glucose and maltose.

\subsection{Encapsulation Efficiency of the CDs/OEO}

The encapsulation efficiency of the CDs/OEO was $35 \%(\mathrm{w} / \mathrm{w})$. This parameter is dependent mainly the factors such as molecular ratios, encapsulation method, and interactions between matrices and essential oils. ${ }^{[24]}$ Wen et al. ${ }^{[25]}$ characterized the inclusion complex between cinnamon essential oil and $\beta$-CD with a 10:90 molar ratio $(\mathrm{w} / \mathrm{w})$ and found an encapsulation efficiency of $10.8 \%$. Kfoury et al. ${ }^{[26]}$ reported values of encapsulation efficiency ranged from $60 \%$ to $80 \%$ for $\beta$-CD and tarragon essential oil complexes at 3:1 and 6:1 molar ratios, respectively. Abarca et al. ${ }^{[24]}$ evaluated the inclusion complex of 2-nonanone (2-NN) and $\beta$-CD prepared by a co-precipitation method and reported encapsulation efficiency values ranging between $34.8 \%$ and $1.9 \%$ using 1:0.5 and 1:2 molar ratios, respectively.

\subsection{TGA/DTA Analysis of CDs/OEO}

The thermal stability of the inclusion complex, OEO, and CDs was determined using TGA/DTA curves (Figure 2). This method is efficient to investigate the thermal stability of the inclusion complex. Due to inclusion complexation with CDs, the temperature of evaporation of guest molecules was increased owing to their interactions with host molecules. ${ }^{[27]}$

The initial and final decomposition temperatures of the CDs were 252.9 and $321.0^{\circ} \mathrm{C}$, respectively, with a $47.4 \%$ weight loss. The derivative thermogravimetry curve showed only at one stage of thermal decomposition, in which the main degradation of CD molecules occurred. The TGA thermogram of OEO showed one major weight loss $(94.7 \%)$ due to its evaporation around $135{ }^{\circ} \mathrm{C}$ indicating its highly volatile nature. On the other hand, inclusion complex delayed the thermal decomposition of the OEO and its thermogram had two stages. The first stage with a $48.0 \%$ mass loss can be attributed to the evaporation of OEO $\left(293{ }^{\circ} \mathrm{C}\right)$ and the second stage $\left(421.8^{\circ} \mathrm{C}\right)$ attributed to the main degradation of CD with an additional $23.0 \%$ reduction in mass. Celebioglu et al. ${ }^{[28]}$ characterized the thymol/CD inclusion complex by thermogravimetric analysis and found the same behavior in the inclusion complex thermograms, with stages of weight loss that corresponded to thymol evaporation and main degradation of $\mathrm{CD}$ (above $300^{\circ} \mathrm{C}$ ).

In the inclusion complex, there is no evidence of the presence of OEO at decomposition temperature $\left(127^{\circ} \mathrm{C}\right.$, Figure $\left.2 \mathrm{~b}\right)$, suggesting that the formation of the inclusion complex increased the thermal stability of the essential oil, thus retarding its decomposition. According to Yildiz et al., ${ }^{[29]}$ the enhanced thermal stability of the essential oil is indicative of inclusion complexation between CD and guest molecules. Munhuweyi et al. ${ }^{[30]}$ produced $\beta$-CD microcapsules containing cinnamon and oregano essential oils, and observed a shift in the thermal degradation of the guest molecule after complexation with CD. These changes were attributed to a chemical interaction and to the presence of a guest molecule in the complex that enhanced the thermal stability of volatile compounds.

\section{Conclusions}

The germination process of wheat influenced the CD production promoting the highest conversion yield $(54.4 \%)$ at the lowest starch concentration (1\%) used. Besides the conversion yields, the starch concentrations influenced the $\alpha$-, $\beta$-, and $\gamma$-CD contents. The lowest starch concentration produced mainly $\beta$-CD; and the highest starch concentration (10\%), $\gamma$-CDs. The inclusion complex produced with CDs from germinated wheat starch increased the thermal stability of the OEO, promoting their protection at high temperatures. Thus, the germinated wheat starch may be a promising substrate for the CD production, adding value to this product that is, normally, not used by the food industry. The results obtained suggest that CDs produced from germinated wheat starch can be used to encapsulate compounds highly volatile and unstable at high temperatures.

\section{Experimental Section}

Materials: Germinated wheat grains with preharvest sprouting and non-germinated wheat grains BRS Marcante cultivar (Triticum aestivum L.) were used. The wheat samples were supplied by Embrapa Trigo (Passo Fundo, RS, Brazil). The CD glycosyltransferase enzyme (Toruzyme $3.0 \mathrm{~L}$ ) was kindly provided by Novozymes A/S (Denmark). The OEO was isolated by hydrodistillation according to the method described by Kringel et al. ${ }^{[3]]}$

Milling of Grains: The wheat grains were conditioned to $15 \%$ (wet basis; w.b.) moisture with distilled water for $24 \mathrm{~h}$, then milled in an experimental roll mill (Chopin, Moulin CD 1, France), according to the 26-10.02 method of the American Association of Cereal Chem. ${ }^{32]}$

Extraction of Wheat Starch: The wheat starch was extracted from the white wheat flour according to Knight, Olson. ${ }^{[33]}$ After the process, the starch was dried in an oven with air circulation at $40^{\circ} \mathrm{C}$ for $16 \mathrm{~h}$ for further analysis.

Chemical Composition of the Wheat Starch: The moisture content at $105{ }^{\circ} \mathrm{C}$, ash at $600{ }^{\circ} \mathrm{C}$, lipids by solvent extraction, and crude protein 

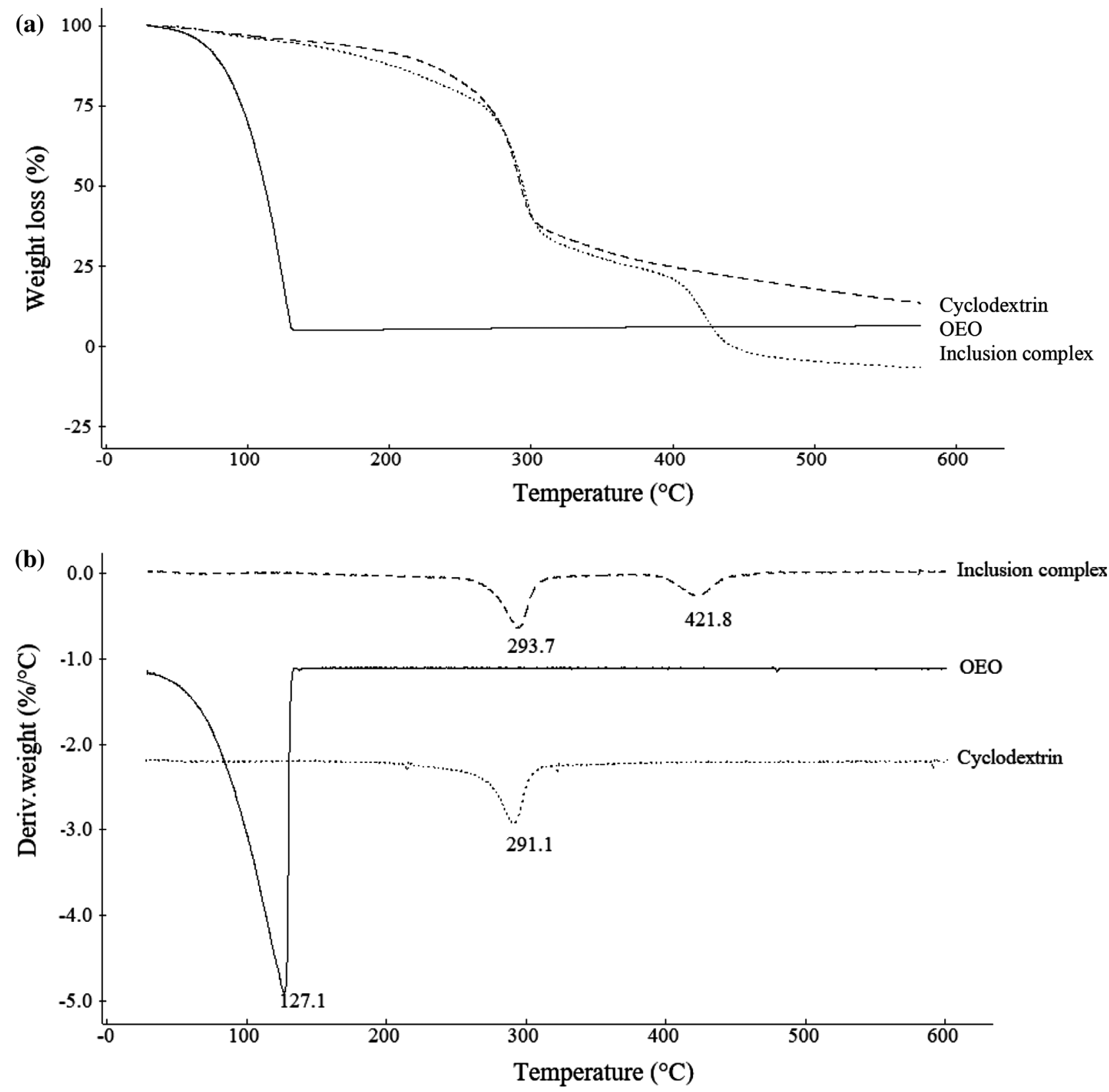

Figure 2. a) TGA and b) DTA thermograms of inclusion complex, OEO, and cyclodextrins.

$(\mathrm{N} \times 5.7)$ were determined according to the AACC International[32] $44-$ 15.02, 08-12.01, 30-25.01, and 46-13.01 methods, respectively.

Amplolytic and Alpha-Amylase Activities in the Whole Wheat Milled Grains and Starch: The amylolytic and alpha-amylase activities were determined in the milled whole wheat grains and wheat starches (germinated and nongerminated) following the methodology described by Saman et al. ${ }^{[34]}$ The extraction of the enzyme was conducted by suspending $1 \mathrm{~g}$ of sample in $10 \mathrm{~mL}$ of a $0.2 \%$ calcium chloride solution, mixed by vortexing for $1 \mathrm{~min}$ and centrifugation at $1000 \times \mathrm{g}$ for $10 \mathrm{~min}$. The supernatant was used to measure the enzyme activity (enzymatic extract).

The amylolytic activity was determined by incubation of $0.5 \mathrm{~mL}$ of the enzymatic extract in a substrate composed of soluble starch from potato obtained from Sigma-Aldrich $\left(\mathrm{C}_{6} \mathrm{H}_{10} \mathrm{O}_{5}\right.$, CAS 9005-84-9) solution $1 \%$ in acetate buffer $(100 \mathrm{~mm}, \mathrm{pH} 5.5)$. The samples were incubated at $60{ }^{\circ} \mathrm{C}$ for $5 \mathrm{~min}$ and the reducing sugars were evaluated by the DNS (dinitro salicylic acid) method. One unit of amylolytic activity $(U)$ is considered as the amount of enzyme required to release $1 \mu \mathrm{mol}$ maltose $\mathrm{min}^{-1}$.

The activity of the alpha-amylase enzyme was determined using the same method for amylolytic activity, changing the conditions of temperature and incubation time. The mix of the enzyme extract and substrate was incubated at $70^{\circ} \mathrm{C}$ for $15 \mathrm{~min}$ to inactivate the $\beta$-amylase and $\alpha$-glycosidase. One unit of $\alpha$-amylase activity $(U)$ is considered as the amount of enzyme required to release $1 \mu \mathrm{mol}$ maltose $\mathrm{min}^{-1}$.

Production of CDs from Wheat Starch: CDs were produced according to the methodology proposed by Alves-Prado et al. ${ }^{[35]}$ with some modifications. Wheat starches ( $1 \%$ and $10 \% ; \mathrm{w} / \mathrm{v}$ ) were prepared in an acetate 
buffer, $100 \mathrm{~mm}, \mathrm{pH}$ 5.5, and gelatinized in a water bath; and 1.5\% (w/v) of the CD glycosyltransferase enzyme was added to $100 \mathrm{~mL}$ of each gelatinized substrate. These conditions of concentrations were predetermined by preliminary tests. Then, the samples remained in a digester water bath at $55^{\circ} \mathrm{C}$ under stirring at 120 cycles $\mathrm{min}^{-1}$ for $24 \mathrm{~h}$. At the end of the reaction, the suspension was maintained at $90^{\circ} \mathrm{C}$ for $10 \mathrm{~min}$ to inactivate the enzyme, and after centrifugation, to collect the supernatant, which was stored at $4{ }^{\circ} \mathrm{C}$ in airtight vials, for further analysis.

Concentrations of the CDs Produced From Wheat Starch: The concentrations of $\alpha, \beta$, and $\gamma$-CDs produced by the enzymatic modification of wheat starches were determined by an HPLC system (Shimadzu, Tokyo, Japan) equipped with a refractive index detector (Shimadzu, RID-10A) and Aminex HPX-42A column (Bio-Rad), a particle size of $5 \mathrm{~mm}$, a $25 \mathrm{~cm}$ length, and a $4.6 \mathrm{~mm}$ internal diameter. The used mobile phase was acetonitrile and water $(65: 35 ; \mathrm{v} / \mathrm{v})$ at a flow rate of $0.5 \mathrm{~mL} \mathrm{~min}^{-1}$ at room temperature $\left( \pm 25^{\circ} \mathrm{C}\right)$. Standards $(\alpha, \beta$, and $\gamma-\mathrm{CD})$ obtained from SigmaAldrich (St. Louis, USA) and samples were filtered through a membrane of $0.45 \mathrm{~mm}$. Analytical curves for $\alpha, \beta$, and $\gamma$-CDs were made at different concentrations. The results of the peak areas of each CD were adjusted by linear regression and the LOQs and LODs were calculated.

Reducing Sugars Analysis: The determination of reducing sugars was accomplished by the DNS (3,5-dinitro salicylic acid) method, according to the methodology described by Miller, ${ }^{[36]}$ with some modifications. The solution containing $200 \mu \mathrm{L}$ of CDs and $200 \mu \mathrm{L}$ of DNS solution was heated in a water bath at $100^{\circ} \mathrm{C}$ for $5 \mathrm{~min}$ and subsequently cooled in cold water. After that, $1.6 \mathrm{~mL}$ of distilled water was added and the spectrophotometric reading was performed at $540 \mathrm{~nm}$. The results were expressed in milligram equivalent of reduced sugar per milliliter of sample, by performing the standard curve of glucose.

Preparation of CDs/OEO Inclusion and Encapsulation Efficiency (\%): The inclusion complex between cyclodextrins from germinated wheat starch (1\%) and OEO was prepared according to Kringel et al. ${ }^{[31]}$ with some modifications. Due to the complexity of the CDs separation process as well as the high cost involved in this operation, which would make the process economically unfeasible, the separation of CDs has not been performed. Therefore, a mixture of $\alpha-, \beta$-, and $\gamma$-CDs were used to produce the inclusion complex. The 1:1 (w/w) molar ratio between CDs and OEO was defined by preliminary tests. CDs (mixture of $\alpha-, \beta$-, and $\gamma$-CDs; $2 \mathrm{~g}$ ) were dissolved in distilled water $(10 \mathrm{~mL})$, maintained at $35^{\circ} \mathrm{C}$ on a hot plate, and essential oil $(2 \mathrm{~g})$ was slowly added to the solution. These suspensions were stirred overnight at room temperature $\left(20^{\circ} \mathrm{C}\right)$. The solution obtained was dried in an oven with forced air circulation at $35^{\circ} \mathrm{C}$ for $24 \mathrm{~h}$ and stored under refrigeration at $4{ }^{\circ} \mathrm{C}$ in sealed vials.

The encapsulation efficiency $(E E)$ was performed according to Ghasemi et al. ${ }^{[37]}$ with some modifications. The surface and total OEO contents present in the inclusion complex were analyzed. The surface OEO content was determined by dispersing a $0.5 \mathrm{~g}$ sample in $20 \mathrm{~mL}$ of hexane; this dispersion was mixed for $20 \mathrm{~min}$ in a magnetic stirrer and filtered using Whatman no. 41 filter paper, followed by spectrophotometric analysis at $231 \mathrm{~nm}$. In the determination of the total OEO content present in inclusion complex, a $0.5 \mathrm{~g}$ sample was dissolved in $20 \mathrm{~mL}$ of distilled water and mixed to dissolve completely. Then, $20 \mathrm{~mL}$ of hexane was added to the prepared solution and mixed for extra $5 \mathrm{~min}$. This solution was centrifuged at $3500 \mathrm{rpm}$ for $20 \mathrm{~min}$. The supernatant was collected to determine the total OEO by spectrophotometric analysis at $231 \mathrm{~nm}$. A standard curve of OEO was prepared with different concentrations $\left(2-8 \mu \mathrm{g} \mathrm{mL} \mathrm{L}^{-1}\right)$, followed by examining the solution's absorbance. The EE was calculated according to Equation (1).

EE $(\%)=\frac{\text { Total amount of oil }- \text { surface oil amount }}{\text { Total amount of oil }} \times 100$

Thermogravimetry/Derivative Thermogravimetry Analysis of CDs/OEO: The decomposition temperatures and weight loss (\%) due to decomposition inclusion complex, OEO and CDs produced from germinated wheat starch were determined using a thermogravimetric analyzer (TCA, TA-60WS, Shimadzu, Kyoto, Japan). Thermogravimetry/derivative thermogravimetry (TCA/DTA) curves were recorded under dynamic nitrogen atmosphere $\left(50 \mathrm{~mL} \mathrm{~min}^{-1}\right)$ by heating the samples $( \pm 5 \mathrm{mg})$ from 30 to $600^{\circ} \mathrm{C}$ with a heating rate of $10^{\circ} \mathrm{C} \mathrm{min}-1$.

Statistical Analysis: Analytical determinations for the samples were performed in triplicate, except for the concentrations of the CDs. A comparison of the two groups was performed by a $t$-test at a $5 \%$ level.

\section{Acknowledgement}

This study was financed in part by the Coordenação de Aperfeiçoamento de Pessoal de Nível Superior-Brasil (CAPES) —Finance Code 001, CNPq, FAPERGS and the Center of Southern Electron Microscopy (CEME-SUL) of the Federal University of Rio Grande (FURG).

\section{Conflict of Interest}

The authors declare no conflict of interest.

\section{Keywords}

amylolytic activity, cyclodextrins, germination, inclusion complex, wheat starch

Received: March 18, 2019

Revised: October 18, 2019

Published online:

[1] L. K. Brown, A. T. Wiersma, E. L. Olson, J. Cereal Sci. 2018, 79, 311.

[2] J. Baranzelli, D. H. Kringel, R. Colussi, F. F. Paiva, B. C. Aranha, M. Z. Miranda, E. R. Zavareze, A. R. G. Dias, LWT 2018, 90, 483.

[3] J. Baranzelli, D. H. Kringel, J. F. Mallmann, E. Bock, S. L. M. El Halal, L. Prietto, E. R. Zavareze, M. Z. Miranda, A. R. G. Dias, Starch - StÃrke 71, 2019, 1800262.

[4] S. V. Kurkov, T. Loftsson, Int. J. Pharm. 2013, 453, 167.

[5] C. Santos, P. Buera, F. Mazzobre, Curr. Opin. Food Sci. 2017, 16, 106.

[6] A. S. S. Ibrahim, M. A. El-Tayeb, Y. B. Elbadawi, A. A. Al-Salamah, Electron J. Biotech. 2011, 14, 1.

[7] J. N. Schöffer, C. R. Matte, D. S. Charqueiro, E. W. Menezes, T. M. H. Costa, E. V. Benvenutti, R. C. Rodrigues, P. F. Hertz, Process Biochem. 2017, 58, 120.

[8] K. H. Pinheiro, L. S. Watanabe, S. L. Nixdorf, C. E. Barão, T. C. Pimentel, G. Matioli, F. F. de Moraes, Starch - StÃrke 70, 2018, 1800073.

[9] H. Pinkaew, M. Thongngam, Y. -J. Wang, O. Naivikul, J. Cereal Sci. 2016, 70, 116.

[10] J. Xu, H. Zhang, X. Guo, H. Qian, J. Sci. Food Agric. 2012, 92, 380.

[11] P. Wang, K. Liu, Z. Gu, R. Yang, Food Chem. 2018, 269, 473.

[12] P. Kajla, A. Sharma, D. R. Sood, Asian J. Dairy Food Res. 2017, 36, 52.

[13] P. Van Hung, T. Maeda, S. Yamamoto, N. Morita, J. Sci. Food Agric. 2012, 92, 667.

[14] Y. Pomeranz, Wheat: Chemistry and Technology, Vol. 3. AACC, St. Paul, MN 1988, pp. 97-158.

[15] J. A. Delcour, R. C. Hoseney, Principles of Cereal Science and Technology. AACC International, New York 2010.

[16] D. Kalita, B. Sarma, B. Srivastava, Food Chem. 2017, 220, 67.

[17] N. De Brier, S. Hemdane, E. Dornez, S. V. Gomand, J. A. Delcour, C. M. Courtin, J. Cereal Sci. 2015, 62, 66.

[18] A. M. M. Sakinah, A. F. Ismail, R. M. Illias, A. W. Zularisam, O. Hassan, T. Matsuura, Sep. Purif. Technol. 2014, 124, 61.

[19] J. N. Schöffer, M. P. Klein, R. C. Rodrigues, P. F. Hertz, Carbohydr. Polym. 2013, 98, 1311.

[20] J. Rakmai, B. Cheirsilp, Biochem. Eng. J. 2016, 105, 107. 
[21] V. A. McKie, B. V. McCleary, J. Cereal Sci. 2015, 64, 70.

[22] L. Wang, D. Wu, J. Chen, J. Wu, Food Chem. 2013, 141, 3072.

[23] A. M. M. Sakinah, A. F. Ismail, O. Hassan, A. W. Zularisam, R. M. Illias, Desalination 2009, 239, 317.

[24] R. L. Abarca, F. J. Rodríguez, A. Guarda, M. J. Galotto, J. E. Bruna, Food Chem. 2016, 196, 968.

[25] P. Wen, D. Zhu, K. Feng, F. Liu, W. Lou, M. Li, M. Zong, H. Wu, Food Chem. 2016, 196, 996.

[26] M. Kfoury, L. Auezova, S. Ruellan, H. Greige-Gerges, S. Fourmentin, Carbohydr. Polym. 2015, 118, 156.

[27] S. Zhang, H. Zhang, Z. Xu, M. Wu, W. Xia, W. Zhang, Ind. Crops Prod. 2017, 95, 60 .

[28] A. Celebioglu, Z. I. Yildiz, T. Uyar, Food Res. Int. 2018, 106, 280.

[29] Z. Y. Yildiz, A. Celebioglu, M. E. Kilic, E. Durgun, T. Uyar, J. Food Eng. 2018, 224, 27.
[30] K. Munhuweyi, O. J. Caleb, A. J. Van Reenen, U. L. Opara, LWT 2018, $87,413$.

[31] D. H. Kringel, M. D. Antunes, B. Klein, R. L. Crizel, R. Wagner, R. P. Oliveira, A. R. G. Dias, E. R. Zavareze, J. Food Sci. 2017, 82, 2598.

[32] AACC. Approved methods of the American Association of Cereal Chemists (AACC International), 11th ed., AACC, St. Paul, MN 2010.

[33] W. Knight, R. M. Olson, Starch Chemistry and Technology, Academic Press, New York 1984, pp. 491-506.

[34] P. Saman, J. A. Vázquez, S. S. Pandiella, Process Biochem. 2008, 43, 1377.

[35] H. F. Alves-Prado, A. A. J. Carneiro, F. C. Pavezzi, E. Gomes, M. Boscolo, C. M. L. Franco, R. Silva, Appl. Biochem. Biotechnol. 2008, 146, 3.

[36] G. L. Miller, Anal. Chem. 1959, 31, 426.

[37] S. Ghasemi, S. M. Jafari, E. Assadpour, M. Khomeiri, Carbohydr. Polym. 2017, 177, 369. 